\title{
CONVICTION AND RATIONALITY
}

\author{
STEVEN JAMES BARTLETT
}

\author{
KEYWORDS: conviction, rationality, the rational \\ bridge problem
}

\section{INTRODUCTORY NOTE}

uring the academic year 1969-70, at the still-idealistic age of 24, I read the very
short paper that follows before the imposing Robert Hutchins and the Fellows of the Center for the Study of Democratic Institutions. The paper was, and still is, now nearly half a century later, the statement of an enduring personal precept, and also an implicit encomium to individuals whose psychology establishes a dependable bridge between their rational convictions and their conduct.

Much later, I have referred to the unreliability of this link between rationality and behavior as posing "the rational bridge problem"-in reference to the great many people for whom such a bridge is exceedingly shaky to non-existent. In many ways, the rational bridge problem is similar to what I have called "the moral bridge problem," which directs attention to the degree of "moral intelligence" of people and the frailty of the connection between their moral reasoning and their resulting behavior.*

\footnotetext{
* Steven James Bartlett, The Pathology of Man: A Study of Human Evil, Chapter 18. Springfield, IL: Charles C. Thomas, 2005. See also the earlier publication, Steven James Bartlett, "Roots of Human Resistance to Animal Rights: Psychological and Conceptual Blocks," Animal Law, Vol. 8, 2002, pp. 143-76. Electronically re-published in 2002 by Michigan State University's Detroit College of Law, Animal Law Web Center [http://www.animallaw.info/articles/arussbartlett2002.htm]. Translated and published online in German [http://www.simorgh.de/animallaw/bartlett 33-67.pdf]; translated and published in Portuguese: "Raízes da resistência humana aos direitos dos animais: Bloqueios psicológicos e conceituais," Brazilian Animal Rights Review (Revista Brasileira de Direito Animal), Vol. 2(3), July/December, 2007. Also available online: [https://www.animallaw.info/sites/default/files/brazilvol3.pdf].
} 
The author has chosen to issue this paper as a free open access publication under the terms of the Creative Commons Attribution-NonCommercial-NoDerivs license, which allows anyone to distribute this work without changes to its content, provided that both the author and the original URL from which this work was obtained are mentioned, that the contents of this work are not used for commercial purposes or profit, and that this work will not be used without the author's or his executor's permission in derivative works (i.e., you may not alter, transform, or build upon this work without such permission). The full legal statement of this license may be found at

http://creativecommons.org/licenses/by-nc-nd/4.0/legalcode

(c) (i) (9)

C 2016 Steven James Bartlett 


\section{CONVICTION AND RATIONALITY ${ }^{\dagger}$}

\section{STEVEN JAMES BARTLETT}

[F]or Socrates the essential characteristic of all the oral arguments which he pursues is not truth but conviction; the conviction which welds belief to action. It is perhaps this faith which is at the root of Socrates' assurance that virtue is knowledge.

- Alexander Sesonske (1961, p. 34)

$\mathrm{n}$ this way, Sesonske, in his article "Plato’s Apology, Republic I," ${ }^{\ddagger}$ draws attention
to the Socratic concern that argument must go hand-in-hand with the conviction which leads from the realm of philosophic discourse to the world of practical action. The strength of the link between valid argument and commitment to its conclusions as a guide for action depends on the extent to which the argument has persuasive force and can convince us that what is true should be adopted by us in our everyday lives.

It is clear in the Meno and in the Republic that Plato did not consider that true knowledge could be bestowed on another; rather, it came only through a dialectical involvement in questioning. This process of question and answer, which in Plato assumes the form of dialogue, is governed by the supposition that if truths are arrived at, those who are involved in dialogue will be compelled by the force of the argument to acknowledge these truths. Not only will they come to accept these truths, but with this acknowledgment will come a fundamental conviction that will overflow the boundaries of argumentation and will influence them to live according to the truths which they have been persuaded to affirm.

t A short paper read before the Fellows of the Center for the Study of Democratic Institutions, Santa Barbara, California, during the academic year 1969-70.

\#Alexander Sesonske, “Plato’s Apology, Republic I,” Phronesis, 6, 1961, pp. 29-36. 
It is clear that this connection between argument and practical affairs, between knowledge and action, between the conceptual affirmation of principles and influence upon daily behavior, can and does break down. It breaks down, as Sesonske suggests, when there is refusal to listen to the argument, when "the hubbub of Demos" drowns out the voice of reason, or when the spoken words are taken as a game, lacking in seriousness.

It was against this breakdown that Plato fought. But why? Why not accept the breakdown and give up the attempt to persuade and convince?. Why was the connection between knowledge and action essential to Plato's outlook? It is this question which I would like to explore briefly.

To Greek thinkers, reason is the very condition of man's moral being; by reason they understood that in man which permits him to live for something. The rationality of man is that which enables man to have ideals. The notion of an ideal involves that which is never totally realized, while it also involves that which is in a process of realization. It is by virtue of reason that man can think beyond the moment and live for an end.

It follows that in the Greek conception, the moral life is practically identical with the rational life. The best life is the one lived according to the prescriptions of rationality, for it is the life in which action and thought are wedded as means to the end or telos of life, which Plato calls the Good.

Reason is the ultimate condition of morality; it is also the ultimate condition of understanding. An object is intelligible insofar as it is organized according to an end or principle which we must suppose in order to explain it. The more we can detect the function, end, or imminent principle of anything, the more we may understand it. 
A man's life is good in proportion as it exhibits a purpose which directs his action; the more a man's life assumes a structure and a plan by virtue of rational goals, the more his life is good. Man's life becomes intelligible and good in proportion as rationality serves to guide his thought and action.

Now the connection between rationality and life led according to its prescriptions is conviction. Conviction is the essential link between reasonable, intelligent, moral action. When this link breaks, Plato's concerns begins. His is a concern to maintain and to strengthen the bridge between the reasonable and the desirable; without this tie, morality is rendered impossible. 